\title{
ELT Assessment Patterns Dictate Teaching-Learning Approaches: A Hindrance to Map out Employability and Life Skills
}

\author{
Muhammad Khan Abdul Malik \\ ${ }^{1}$ Assistant Professor, College of Arts \& Humanities (English Department), Jazan University, Jazan, Kingdom of \\ Saudi Arabia \\ Correspondence: Muhammad Khan Abdul Malik, College of Arts \& Humanities (English Department), Jazan \\ University, Jazan, Kingdom of Saudi Arabia. E-mail: dr.muhammadkhan786@gmail.com
}

Received: February 25, $2021 \quad$ Accepted: May 2, $2021 \quad$ Online Published: May 8, 2021

doi:10.5539/ijel.v11n3p74 URL: https://doi.org/10.5539/ijel.v11n3p74

\begin{abstract}
There is a plethora of research on the multifarious dialogues on English Language as (EFL and ESL), its teaching-learning approaches, assessment patterns, the learners' employ ability and their life skills. How all these aspects affect and influence one another, need further exploration. The most important and vital point is that English Language and Literature syllabus may be different in different colleges and universities but the assessment patterns are approximately the same. The alarming situation is that maximum questions are responded through cramming and rote learning where there is no reflection of creative skills and competency in English Language. However, exceptions are always there. The focus and significance of the present study is "how can the ELT approaches and assessment patterns be adapted and transformed specifically to meet the demand of the labor market, employability and life skills. (i) the researcher collected and analyzed 75 Question Papers of English from the Kingdom of Saudi Arabia, India, Bangladesh and Pakistan, and (ii) developed questionnaires cum opinionnaires for the 50 ELT teachers and the students in Jazan University, Jazan (KSA), and administered online. To determine findings and conclusion, the collected data have been analyzed in the employability, life, and soft skills perspectives that confirmed the validity and reliability of the present research hypothesis.
\end{abstract}

Keywords: EFL, ESL, assessment, teaching-learning, ELT approaches, employability, life-skills, soft-skills, washback

\section{Introduction}

The teaching-learning of EFL and ESL is mandatory in national public education policy of approximately 142 countries (outer circle) in the world. There are about 41 countries in which English language is a possible elective subject at different levels of studies (Global English Education Policy, Para 1). This shows the importance of its appropriate teaching and learning. Apparently, all universities and colleges have predetermined aims and goals for their input and output at national and international levels; specifically English Program Learning Outcomes (PLOs) and Course Learning Outcomes (CLOs) but unfortunately and actually Students' Learning Outcomes (SLOs) are still a dream with some exceptional cases. The process of diagnostic, formative and summative assessments reflects the real situation. The majority of the graduates reproduce others ideas in others' language and they are not creative writers which is so shocking. In KSA and other parts of the world also, students generally go for good grades and not for knowledge, skills and competency.

Although there is a continuous process of curricula development, faculty development and assessment development, i.e., washback; yet the quality of our EFL \& ESL output is not up to the mark. The question arises, why is this failure despite concerted efforts for an overall improvement? The possible answer is that all relevant aspects of ELT need to be interrogated seriously and honestly. Thereafter whatever is the conclusion that must not be only on the paper instead the gaps should be filled practically to overcome the weaknesses at different levels. This sincere approach may produce the graduates with maximum scope of employability and life skills related to the use of English language in real-life-like situations. If not $100 \%$ but majority should qualify for the international labor market. This is real national mission and expected output against the input of a nation. If someone says that there is nothing wrong with the teaching material, teaching approaches and the level of assessment; this claim is clearly questionable and deniable; all management at different levels have to revisit the 
existing and alarming situation to ensure English language teaching and learning a success. All this is difficult but not impossible, just the management, faculty members, students and parents have to play their roles. The faculty members can do a lot toward development of various and the most wanted skills in English language learners through administrative support.

Teachers are supposed to measure what they teach and teach what tests usually measure (Buck, 1988) Both teacher and students unfortunately, pay attention to what examinations stress, trying to guess what the hot spots are in EFL syllabus. McLaughlin (1991), states that the learners always prepare themselves for test items, to students, studying what does not count in examinations, is considered a waste of time. The prevailing context reflects that all components - assessment, teaching approaches, the teacher, the taught and curriculum are moving in a tightly fixed framework hence the development of critical thinking, creativity, analytical approach and employability and life skills, is still a dream. In a word the stakeholders concerned are to evaluate the assessment process whatever, wherever and whenever needed.

\section{Significance of the Study}

The significance of the present study lies in the fact that it touched upon the core issue of the evaluation of assessment patterns, teaching practices with reference to the employability and life skills that the English language graduates lack in general. Unfortunately, they have no idea of employers' demand even if they get a job they experience difficulties to remain employable afterwards. The graduates are not at fault instead the system and subsystems are questionable. A total reformation in teaching-learning of EFL is inevitable.

\section{Conceptual Framework}

The conceptual framework of the present study summarized the pros and cons of EFL testing and assessment in past, present and future. Any language test or piece of assessment must have positive washback or backwash, which means that the effect of the test on the teaching must be beneficial. This should be kept in mind by the test constructors; it is only too easy to construct a test which leads, for example, to candidates learning material by heart or achieving high marks by simply applying test-taking skills rather than genuine language skills (Wall, 1997). Language assessment or language testing is a field of study under the umbrella of applied linguistics. The assessment may include listening, speaking, reading, writing, an integration of two or more of these skills, or other constructs of language ability. Although trends in testing, as in other fields, change over time, but some principles of EFL assessment are permanent and are not overly affected by ever changing trends. They need to be held in mind by the EFL teachers whenever they construct a test, whether this is a class quiz, a class essay or summative assessment.

The most important of these principles fall under three categories such as validity, reliability and washback. The term 'washback' refers to the influence of language testing on its teaching and learning" (Cheng et al., 2004). In testing and assessment, if there is no possible way to test the hypotheses created by the relationship between observable variables, and constructs, the theory is meaningless, or 'scientifically not admissible'. "Classroom assessment is an essential component of teaching and learning. Still, the literature on language testing often highlights teachers' perceptions of designing classroom assessments with little concern about students' perceived realities" (Pan, 2020). The demand of the present era is that different perceptions should have some evidences for their validity.

The last era, i.e., the 20th century witnessed a situation wherein both teaching process and assessment process were teacher-centered. Weir (1987) mentions that there was no role given to the learner except receiving knowledge from the teacher. The function of the assessment was just to award grades. Similarly, Brown et al. (1984) state that the emphasis in the past was on summative assessment as the purpose was to sort out the students for grades and classification for further studies. That's how that era was criticized because of over-reliance on the subjective judgment of the teacher and no interference of the stakeholders. Moreover, there was disintegration between the teaching process and assessment process. The present era of 21 st century formed the assumption that learning is change that can be noticed, in the learner's behavior which can also be measured in quantitative terms. In some situations, the use of scoring instruments has had the most significant impact on performance-driven pedagogy. "Many teachers we spoke with; said that they use scoring rubrics as "scaffolding" for setting performance expectations for their students" (Khattri et al., 1998).

Buck (1988) describes the washback that there is a natural tendency for both teachers and students to tailor their classroom activities to the demands of the test, especially when the test is very important to the future of the students, and pass rates are used as a measure of teacher success. This influence of the test on the classroom (referred to as washback) is, of course, very important. Thus, Buck's definition stresses the impact of a test on what teachers and students do in classrooms (Kathleen, 1999). Five of Alderson and Wall's (1993) restatements 
of the washback hypothesis directly address learners' washback: (i) a test will influence learning, (ii) a test will influence what learners learn, (iii) a test will influence how learners learn, (iv) a test will influence the rate and sequence of learning and (v) a test will influence the degree and depth of learning. Three other points of the hypothesis refer to both teaching and learning: (i) a test will influence attitudes to the content, method of teaching and learning, (ii) the tests will have washback on all learners and teachers, (iii) the tests will have washback effects for some learners and some teachers, but not for others.

Additional skills such as effective communication, soft skills and ability to maintain life-long learning and professional skills are inevitable for the international labour market. Generally, EFL learners at graduation level are not ready for what the employers demand or remain to be employable once they get some job because they lack certain job-related skills. Employability skills are always used for the benefit of the individual himself or herself, the workforce, and ultimately the national economy. Pooja (2013) is of the view that employability skills generally include - (i) performance through effective communication, (ii) attitudinal and transferable skills, (iii) self-management skills; personal attributes such as self-confidence, self-control, and so on. Firstly, to meet the employers' demand of employability and secondly remaining employable these skills are inevitable. In a word these skills are part and parcel of practical life.

'Validity' in testing and assessment has traditionally been understood to mean discovering whether a test 'measures accurately what it is intended to measure'. This view of validity presupposes that when we write a test we have an intention to measure something, that the 'something' is 'real', and that validity enquiry concerns finding out whether a test 'actually does measure' what is intended to measure. The EFL learners should prepare themselves for the rough and tough life outside the classroom. The required transformations in curriculum, instruction, and assessment will move beyond their current testing systems to new systems of assessment that may be able to support the development of deeper learning skills. "It resolves to provide teachers a baseline tool to develop their own critical pedagogy and techniques" (Totanes \& Arceli, 2020). The process of evaluation of an overall framework of EFL assessment, teaching approaches and curriculum should never stop as different theories related to education are always evolving.

\section{Research Question(s)}

The research questions to explore the most specific area of the present study are:

1) Do ELT assessment patterns dictate teaching-learning approaches?

2) Are ELT assessment patterns a hindrance to map out employability and life skills?

\section{Objectives}

The objectives of the study in hand are to:

1) Determine and collect relevant evidences through appropriate washback as to how ELT assessment patterns harness the teaching approaches?

2) Find out how the ELT assessment either formative or summative proves a hindrance to develop EFL learners' employability and life skills.

3) Suggest some suitable and possible solutions how the EFL teacher and the taught can reform the existing situation and develop employability and life skills in classroom and through extra-curricular activities.

\section{Research Methodology}

The present study used Mixed-methods research in washback perspective-(i) the researcher collected and analyzed 75 Question Papers of English from the Kingdom of Saudi Arabia, India, Bangladesh and Pakistan and (ii) developed questionnaires cum opinionnaires for the ELT teachers and the students and administered online, to maximize validity and reliability of the collected data through a cross check of different research tools. To determine findings and conclusion, the collected data have been analyzed in the employability, life, and soft skills perspectives. The data have been displayed in tables and bar-charts for a quick view and ease of the readers.

\section{Data Collection and Data Analysis}

\subsection{The EFL Assessment Patterns at Graduation Level}

A table has been developed to display clearly the most common EFL assessment/test items in Kingdom of Saudi Arabia, India, Bangladesh and Pakistan. This will help in cross checking of similarities and differences in the assessment patterns. Maximum institutions are practicing similar assessment patterns in the sub-continent and Saudi Arabia. The EFL practices of teaching, learning and testing are purely traditional one, which need 
revisiting to keep up pace with the swiftly moving modern world:

Table 1. EFL assessment patterns

\begin{tabular}{|c|c|c|}
\hline Country & Common Objective Questions (Verbs) & Common Subjective Questions (Verbs) \\
\hline KSA & $\begin{array}{l}\text { T/F, Fill in the blanks, Matching, } \\
\text { MCQs, Tick/Cross }\end{array}$ & $\begin{array}{l}\text { Define, Explain, Comment, Differentiate, Discuss, Describe, Demonstrate, } \\
\text { Illustrate, Distinguish, Evaluate, Analyze critically, Compare, Justify, Short \& } \\
\text { Long Question/Answer, Reading comprehension, etc. etc. }\end{array}$ \\
\hline India & $\begin{array}{l}\text { Conversion, Fill in the blanks, Choose } \\
\text { the correct, Matching, Identify, MCQs, }\end{array}$ & $\begin{array}{l}\text { Reading comprehension, Short \& Long Question/Answer, Summary writing, } \\
\text { Essay writing, Critical analysis, Error analysis Description, Make sentences, } \\
\text { Explain, Precis writing, Discuss. }\end{array}$ \\
\hline Bangladesh & $\begin{array}{l}\text { Fill in blanks, MCQs, True/False, } \\
\text { Matching }\end{array}$ & $\begin{array}{l}\text { Short notes, Writing Bibliography, Reading \& Listening comprehension, } \\
\text { Preparing outline, Precis writing, Short and long question/answer, Critical review, } \\
\text { Summary writing, Compare and contrast two authors, Critically analyze, Attempt } \\
\text { critique, Comparison and analysis, Listing arguments, Discuss, Essay writing, } \\
\text { Examine, Elucidate, Comment, Error analysis. }\end{array}$ \\
\hline Pakistan & $\begin{array}{l}\text { MCQs, True/False, } \\
\text { Fill in the blanks, }\end{array}$ & $\begin{array}{l}\text { Short notes, Short \& Long Question/Answer, Discuss, Essay writing, Error } \\
\text { analysis, Use of Idiomatic expression, Letter and application writing, Reading } \\
\text { comprehension, Translation, Dialogue writing, Describe, Narrate, Explain, Define, } \\
\text { Explanation with reference to the context, Elaborate, Critical evaluation, } \\
\text { analysis/views, Differentiate, Recapitulate, Report writing, Compare and contrast, } \\
\text { Highlight, Critical note, Illustrate. }\end{array}$ \\
\hline
\end{tabular}

\section{Analysis Table 1:}

The assessment patterns either objective or subjective type of questions are approximately the same with negligible differences. The subjective part of the assessment in India, Bangladesh and Pakistan is a bit expanded one as compared to Kingdom of Saudi Arabia at graduation level. But unfortunately, there is not a slight touch of the skills that EFL learners need for job market such as communicative skills, soft skills, problem solving, team work, and so on. The EFL faculty is well familiar with the ways the graduate students attempt their questions on critical analysis, critical evaluation, and some other similar questions in final exams. The expected response is creative writing, but maximum attempts are generally through ready-made notes prepared just before the examinations by rote learning. In some places English guess papers (even with solutions) are available and the students definitely opt for that ready-made material for their English examinations. This alarming situation demands the appropriate evaluation of EFL assessment patterns, teaching approaches and curriculum to meet the demand of the $21^{\text {st }}$ century.

\subsection{The EFL Faculty Questionnaire cum Opinionnaire}

There are 25 questions (18 close ended and 7 open ended) to get maximum information based on the EFL faculty experience. 
Table 2. The EFL faculty questionnaire cum opinionnaire

\begin{tabular}{|c|c|c|c|c|}
\hline \multirow[t]{2}{*}{ S/No } & \multirow[t]{2}{*}{ Question } & \multicolumn{3}{|l|}{ Responses } \\
\hline & & Yes $\%$ age & No $\%$ age & $\begin{array}{l}\text { To some } \\
\text { extent } \% \text { age }\end{array}$ \\
\hline 1 & $\begin{array}{l}\text { Do you ensure validity of the test items in the EFL formative and summative } \\
\text { assessments? }\end{array}$ & 75 & - & 25 \\
\hline 2 & Are the test items in your formative and summative assessment the same? & 63 & - & 31 \\
\hline 3 & Do the assessment patterns harness your teaching approaches? & 56 & 31 & 13 \\
\hline 4 & Do you prepare your EFL learners for the predetermined and fixed test items? & 38 & 50 & 12 \\
\hline 5 & $\begin{array}{l}\text { Are you free to make a choice for some test items/activities that may help } \\
\text { developing employability and life skills? }\end{array}$ & 75 & 18 & - \\
\hline 6 & Are problem solving activities and assignments common in your classroom? & 63 & 12 & 25 \\
\hline 7 & Do students' groups present some topics in classroom? & 69 & - & 31 \\
\hline 8 & Are you satisfied with the students' interest and teamwork? & 31 & 25 & 44 \\
\hline 9 & Do your EFL students accept all challenging assignments cheerfully? & - & 37 & 56 \\
\hline 10 & Are your students familiar with the importance of soft skills? & 37 & 25 & 37 \\
\hline 11 & Are you satisfied with the traditional ways of assessments? & 31 & 50 & 19 \\
\hline 12 & $\begin{array}{l}\text { Do you think EFL learners' 'Peer Assessment' is useful for developing their } \\
\text { confidence and creativity? }\end{array}$ & 81 & - & 12 \\
\hline 13 & $\begin{array}{l}\text { Would you like to introduce the idea of students' 'Self-Assessment' in EFL } \\
\text { classroom? }\end{array}$ & 88 & - & - \\
\hline 14 & $\begin{array}{l}\text { Do you think EFL is being taught and assessed as a subject rather than a } \\
\text { language? }\end{array}$ & 44 & 25 & 31 \\
\hline 15 & Are all EFL skills covered in formative and summative assessment? & 56 & 12 & 31 \\
\hline 16 & $\begin{array}{l}\text { The students attempt their traditional EFL assessment tests through their } \\
\text { cramming and rote learning and not as creative writers using critical thinking. Do } \\
\text { you agree? }\end{array}$ & 69 & - & 31 \\
\hline 17 & $\begin{array}{l}\text { Do you think that employability skills can be developed through co-curricular } \\
\text { activities? }\end{array}$ & 81 & - & 19 \\
\hline 18 & $\begin{array}{l}\text { Are your EFL students well motivated to be competent in the use of tangible and } \\
\text { intangible skills for their bright future? }\end{array}$ & 25 & 25 & 50 \\
\hline
\end{tabular}

\section{Table 2 Analysis:}

Majority of the EFL faculty is of the opinion that the EFL formative and summative assessments are valid for testing students' skills and competency. The EFL faculty is free in making choices for certain activities to develop students' employability and life skills. Activities and assignments are common in the EFL classrooms. Peer-assessment and self-assessment is appreciated by the EFL faculty. However, EFL is not being taught and assessed properly as a language needs to be taught and assessed. The EFL learners generally attempt different assessments through their rote-learning. Employability skills can be developed through co-curriculum activities (ESTCCA). To some extent the EFL learners are motivated to be competent in the use of tangible and intangible skills for their bright future. In a word an overall reformation in the EFL teaching, learning and assessment is demand of the time. Moreover, a bar-chart reflecting the most distinctive views of the EFL faculty has been developed for a quick view as follows: 


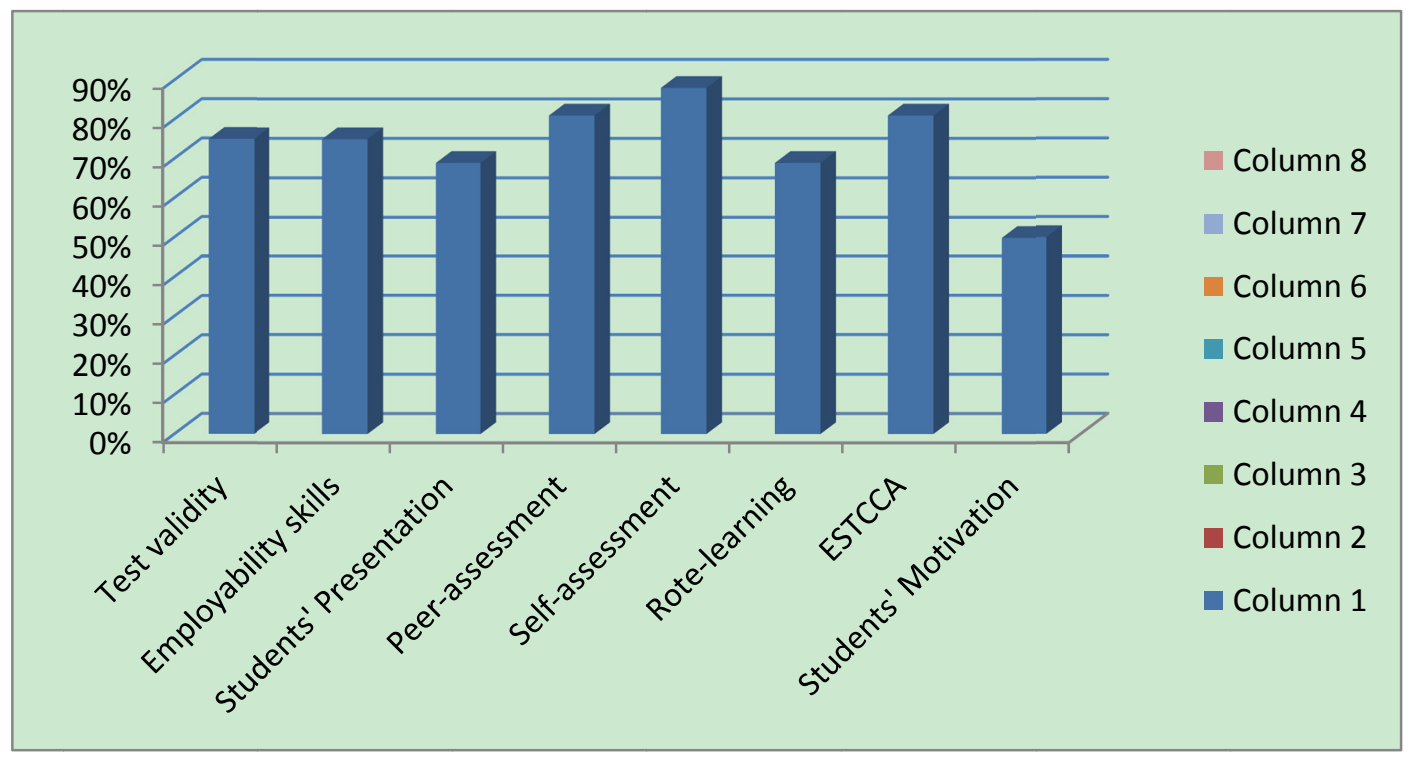

Figure 1. The EFL Faculty Questionnaire cum Opinionnaire)

\section{Responses to Open Ended Questions (Section B, 19-25):}

\section{Q-19: What are the most common test items in EFL assessments: Subjective, Objective or Mixed one?}

The EFL faculty of English Department, College of Arts \& Humanities, Jazan University, Jazan responded that both the formative and summative assessment have mixed questions, i.e., subjective and objective. However, objective questions are usually $25 \%$ only.

\section{Q-20: Your subjective assessment items include (You have to write):}

Generally, the subjective questions may include long answers, detailed explanation, short notes, essay type questions, writing paragraphs, descriptions, narrations, definition, discussion, comments, analysis, comparison, and so on.

\section{Q-21: Your objective test items generally include (You have to write):}

The most common objective type questions are multiple choice questions, true/false statements, fill in blanks and matching.

Q-22: What are the other test's items that you would like to include in the formative and summative assessment of EFL?

Preferably independent writing and reading, presentations, projects, peer group evaluation, students' reflection and writing, performance based assessments, authentic tests, creative writing, group discussions, short speech, creative analysis through critical thinking, classroom presentations, self-assessment/evaluation, This variety of assessment would likely help the students to be competent in their practical life and in achieving higher education which consequently support them to stand in their life.

\section{Q-23: What type of activities and assignments are common is your classroom?}

Some EFL faculty members practice discussion and interaction, written assessment, pair-work, group work activities, project work, quiz, role play, critical reading assignments, presentation, topic related interaction, question-answer sessions, S-S \& T-S sharing of ideas/experiences, quiz competition, exposure of their hobbies, sharing future goals etc. Of course again it depends on the level and course what they study.

Q-24: What does restrain you back from developing the most wanted employability and life skills in EFL teaching? Kindly comment on whatever you experienced so far.

The most common problems are- the deadline to cover the content of the subject, the EFL learners' attitude, predetermined syllabus, overall it's easy to clear the concept to the students through different activities, top-down approach of testing and standardized Common Exam one size fit all tests are strong barriers in giving customized tests for different ability groups, lack of students' motivation, assessment patterns, lack of response from students, lack of language skills on the part of Arab EFL learners and their orthographic problems. Students 
don't have zeal to learn with academic bent of thinking. Students are pampered and mothered by the Saudi teachers. Management and administration are in support for the students. Hence, expats have to restrain back. There is no proper internet facility in the classrooms. Last but not least there is no digital language laboratory to develop language skills, employability skills and soft skills.

\section{Q-25: How can we transform the existing assessment patterns into the prevailing demand of the employers?}

There is always a scope of improvement; where there is a will there is a way. Certain steps such as - making the assessment more relevant and close to the reality, multi-tasking is the need of the hour, useful co-curricular activities, providing proper guidance through negotiated settlement with the stake holders, we have to understand the level of the students, getting rid of common and standardized tests, by keeping constantly in touch with the employers to improve the assessment, developing skills needed to fulfill certain tasks in the workplace, specifying contents that are based on the needs of employers, we need to revisit the course content, teaching approaches and the traditional assessment patterns at all levels and the assessment should be based on real life situations. Let us decide it collectively and introduce the internship courses, e.g., ESP, develop confidence in the students by inculcating the required abilities to meet the demands of the labor market. Management and administration has to provide required facilities to the teachers so that students can be trained to meet the expectations of the society. Obviously, existing assessment patterns can also be transformed to meet the demand of the employers.

\subsection{EFL Learners' Questionnaire cum Opinionnaire}

There are 25 questions (18 close ended with the option of 'Yes', 'No' and 'To some extent', and 7 open ended questions). The open-ended questions are to collect maximum information based on EFL learners' real experiences in their classroom. Table 3 shows responses to the learners' questionnaire cum opinionnaire as follows:

Table 3. EFL responses to learners' questionnaire cum opinionnaire

\begin{tabular}{|c|c|c|c|c|}
\hline \multirow[t]{2}{*}{$\mathrm{S} / \mathrm{No}$} & \multirow[t]{2}{*}{ Question } & \multicolumn{3}{|l|}{ Responses } \\
\hline & & Yes $\%$ age & No $\%$ age & To some extent $\%$ age \\
\hline 1 & $\begin{array}{l}\text { Do you think the test items in the EFL formative and summative } \\
\text { assessments are valid (means fulfill the aims of testing EFL learner' skills } \\
\text { and competency)? }\end{array}$ & 89 & - & 11 \\
\hline 2 & Are the test items in your formative and summative assessments the same? & 33 & 33 & 33 \\
\hline 3 & $\begin{array}{l}\text { Do the assessment patterns harness (control) your EFL study and } \\
\text { preparation for examinations? }\end{array}$ & 72 & - & 22 \\
\hline 4 & $\begin{array}{l}\text { Are you prepared by the English instructor only for the predetermined and } \\
\text { fixed test items? }\end{array}$ & 50 & 27 & 22 \\
\hline 5 & $\begin{array}{l}\text { Are you free to make a choice for some activities that may help developing } \\
\text { your employability and life skills? }\end{array}$ & 89 & - & 11 \\
\hline 6 & $\begin{array}{l}\text { Are problem solving activities and assignments common in your } \\
\text { classroom? }\end{array}$ & 56 & - & 38 \\
\hline 7 & Do students' groups present some topics in classroom? & 78 & 11 & 11 \\
\hline 8 & $\begin{array}{l}\text { Are you satisfied with your classmates' interest and teamwork in } \\
\text { preparation of classroom presentation? }\end{array}$ & 67 & 11 & 22 \\
\hline 9 & $\begin{array}{l}\text { Do you and your EFL classmates accept all challenging assignments } \\
\text { cheerfully? }\end{array}$ & 56 & 22 & 22 \\
\hline 10 & Are you familiar with the importance of soft skills? & 67 & - & 28 \\
\hline 11 & Are you satisfied with the traditional ways of assessments? & 61 & - & 39 \\
\hline 12 & $\begin{array}{l}\text { Do you think the 'Peer Assessment' is useful for developing EFL learners' } \\
\text { confidence and creativity? }\end{array}$ & 61 & - & 33 \\
\hline 13 & Would you like the idea of students' 'Self-Assessment' in EFL classroom? & 56 & 27 & 16 \\
\hline 14 & $\begin{array}{l}\text { Do you think EFL is being taught and assessed as a subject rather than a } \\
\text { language? }\end{array}$ & 39 & 44 & 17 \\
\hline 15 & Are all EFL skills covered in your formative and summative assessment? & 61 & 17 & 22 \\
\hline 16 & $\begin{array}{l}\text { Do you attempt your EFL assessment tests through your cramming and rote } \\
\text { learning and not with critical thinking? }\end{array}$ & 56 & 22 & 22 \\
\hline 17 & $\begin{array}{l}\text { Do you think that your employability skills can be developed through } \\
\text { co-curricular activities? }\end{array}$ & 78 & - & 16 \\
\hline 18 & $\begin{array}{l}\text { Are you as an EFL student well motivated to be competent in the use of } \\
\text { tangible and intangible skills for your bright future? }\end{array}$ & 94 & - & 4 \\
\hline
\end{tabular}




\section{Table 3 Analysis:}

Majority of the students' perception is that their formative and summative assessments are valid for testing their skills and competency. The EFL assessment patterns harness students' learning and preparation for the examinations. Some of the predetermined test items are generally focused by the EFL teachers. The EFL learners are free in making choices to develop certain employability skills. Problem solving activities and assignments are common in the EFL classrooms. Students present some EFL topics in the classrooms. The EFL learners are more or less satisfied with their classmates' interest and teamwork. The students claim that they accept challenging assignments cheerfully. The students like peer-assessment and self-assessment to develop confidence and creativity. The EFL learners are of the view that they can develop employability and life skills through co-curriculum activities. The EFL learners are well-motivated to be competent in the use of tangible and intangible skills for their bright future. The acronyms APHEFLL and ESTCCA used in Figure 2, stand for 'Assessment Patterns Harness EFL Learning' and 'Employability Skills through Co-curriculum Activities' respectively. Furthermore, bar-chart reflecting the most distinctive views of the EFL learners has been developed for a quick view as under:

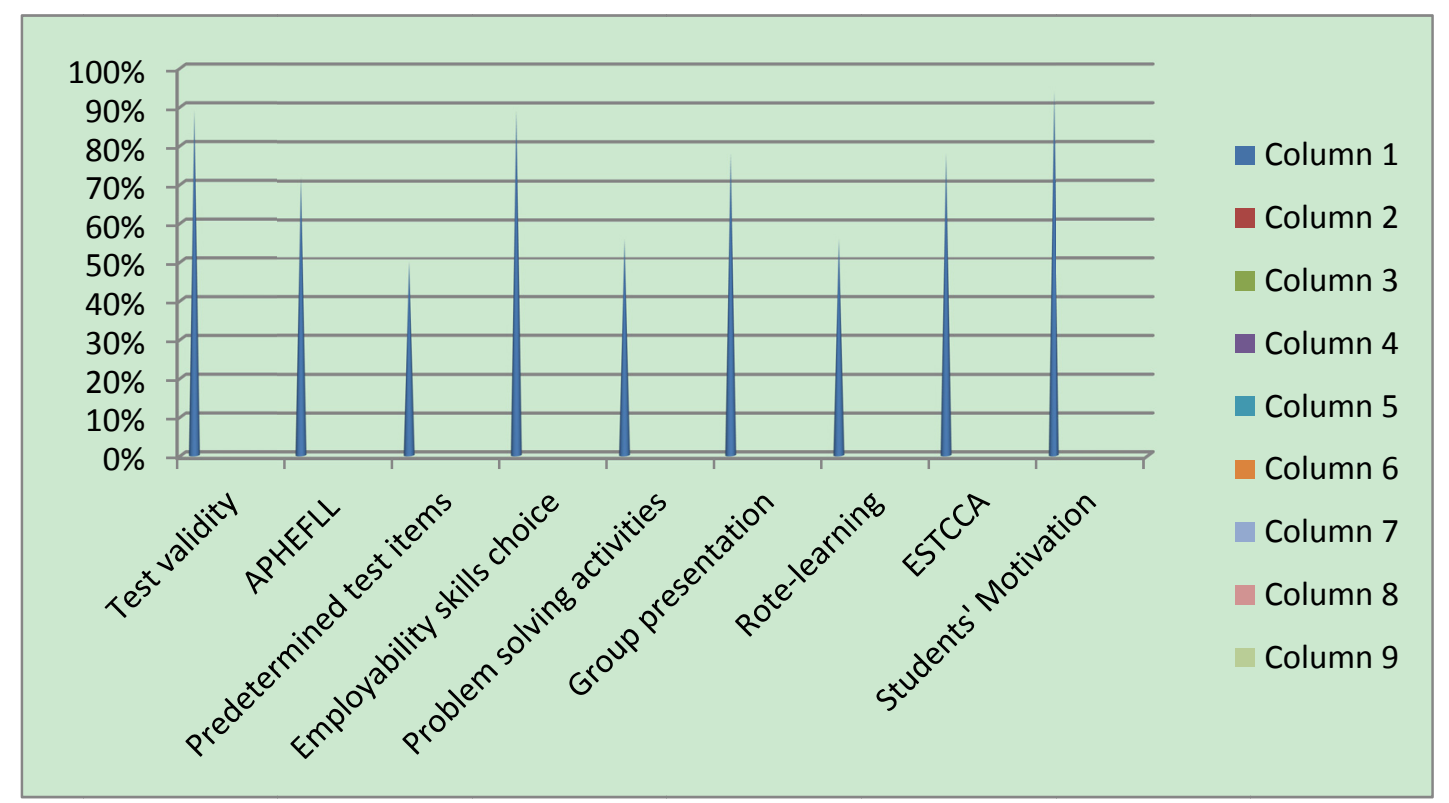

Figure 2. Responses to learners' questionnaire cum opinionnaire

\section{Open Ended Questions (Section B, 19-25):}

\section{Q-19: What are the most common test items in EFL assessments: Subjective, Objective or Mixed one?}

The majority is of the view that the mixture of subjective and objective questions exists everywhere.

\section{Q-20: Your subjective assessment items include (you have to write down):}

Subjective items include paragraph, short and long answer, essay, problem-solving activities.

\section{Q-21: Your objective test items generally include (You have to write):}

Objective items include multiple-choice, true-false, matching and completion.

Students love objective questions because they are a bit easy to answer.

Q-22: What are the other test items that you would like to include in your formative and summative assessment of EFL that may add to your confidence toward using English in real life-like situations?

There must be live listening tests, with several stages such as fill in the blank, choose the correct answer, in order to improve the English as a foreign language. The students' active participation in the process of EFL teaching-learning is vital to build their skills.

Moreover, the role play and going on little trip to a foreign language environment such as some restaurants and companies to interact with them may prove more fruitful. 


\section{Q-23: What type of activities and assignments are common in your classroom?}

At the end of a lecture, question-answer session, writing activities, and discussion on the shared topic, are common.

Q-24: What does restrain you back from developing the most wanted employability and life skills during the EFL learning process? Please comment on whatever you experienced so far.

In fact, time and financial constraints are there. In a specific time both the teacher and students have to complete the predetermined content of the course. Then family problems, lack of motivation and determination, leave the least chance to go for employability skills.

Q-25: How can we transform the existing assessment patterns into the prevailing demand of the employers? Please give some suggestions.

The students are of the view that nothing is impossible. If we are determined at all levels, the existing situation can be improved through certain reformations.

\section{Conclusion}

In the light of a detailed view of the hypothesis, research questions, objectives, data collection and data analysis, the researcher concludes the present study that the positive, well thought and well-planned reforms in the EFL teaching approaches and assessment process is a key to develop overall employability and life skills. The EFL learners' critical thinking, creativity and problem-solving skills must be focused and maximized. On the other hand rote-learning should be minimized. Teacher is an actor, he needs exploiting the course content whatever and classroom situations to develop the most wanted real-life EFL skills. A thorough washback, i.e., the evaluation of assessment process is inevitable in 21 st century.

The goal of the English language learning was, is and will be the development of communicative competence and performance of the learner in real-life-like, ever changing and challenging situations. The EFL assessment and tests have to focus on measuring the learner's communicative skills to decode and encode a meaningful message in different contexts. Teachers believe that teamwork, confidence, communication, creativity and problem solving are the top skills and competencies, developed through extra-curricular activities. Other activities during the school day, such as interacting with peers, support the development of communication and teamwork skills.

How does assessment influence teaching? Assessment affects decisions about grades, placement, advancement, instructional needs and curriculum. Changes in the skills-based knowledge, our students need new learning goals; these new learning goals will change the relationship between assessment and pedagogy. The critical thinking and problem-solving activities and assessment are known to have a positive impact on the quality of students' learning outcomes. Finally, assessment can be viewed as being a means of helping students to learn; a way of reporting on student progress, and a way of making decisions about teaching. Despite sincere efforts, the information collected through the research tools used in the present study or some other similar studies, may not be generalized or guaranteed due to lack of validity and reliability; for, all EFL faculty, EFL learners in different communities may hide the reality just to cover their weak areas. However, a complete but positive washback or backwash, i.e., evaluation of evaluation (assessment) is inevitable to ensure EFL output that may compete in the international labour market for various projects management.

\section{Suggestions}

In the light of the collected data, its analysis and conclusion the researcher suggests some sincere, revolutionary steps and not just commentary (as action speak louder than words) on the part of the stakeholders for the uplifting of the present level of knowledge, skills and competency of the EFL learners that meet the ever-growing demands of the 21st century employers and international labour market as follows:

(a) A comprehensive evaluation of the existing level of EFL assessment, teaching approaches and curriculum,

(b) A valid and reliable survey of the demand and employability skills required by the employers,

(c) Fill in the yawning gap between the existing level of EFL learners' standards and the most wanted employability and life skills,

(d) The EFL learners should be motivated to go for knowledge, skills, competency and values and not just for good grades only.

\section{Recommendation}

Further and regular research in the specific areas of the present study is recommended for better future of the 
EFL learners toward employability and life skills because the EFL teaching and learning is not as simple as to pass the exams with good grades. The research on the language 'use' instead of its 'usage' only, would be highly appreciated.

\section{References}

Alderson, J. C., \& Wall, D. (1993). Does washback exist? Applied Linguistics, 14(2), 115-129. https://doi.org/10.1093/applin/14.2.115

Bailey, K. M. (1999). ToeFL Monograph Series: Washback in Language Testing. New Jersey: Educational Testing Service Princeton.

Brown et al. (1984). Teaching Talk Strategies for Production and Assessment. Cambridge University Press.

Buck, G. (1988). Testing listening comprehension in Japanese university entrance examinations. JALT Journal, $10,12-42$.

Cheng, L., Watanabe, Y., \& Curtis, A. (Eds.). (2004). Washback in language testing: Research contexts and methods. Lawrence Erlbaum Associates Publishers. https://doi.org/10.4324/9781410609731

Global English Education Policy. (2020). Countries in which English Language is a Mandatory or an Optional Subject (interactive). Retrieved September 25, 2020, from https://www.uwinnipeg.ca/global-english-education/countries-in-which-english-is-mandatory-or-optional-su bject.html

Khattri, N., Reeve, A. L., Kane, M. B., \& Adamson, R. (1998). Studies of Education Reform: Assessment of Student Performance. Washington, D.C.: U. S. Department of Education, Office of Educational Research and Improvement. Retrieved from http://www.ascd.org/publications/educational-leadership/nov95/vol53/num03/-How-Performance-Assessme nts-Affect-Teaching-and-Learning.aspx

McLaughlin, M. (1991). Test Based Accountability as a Reform Strategy. Phi Delta Kippan, Feb.

Pan, Y.-C. (2020). Taiwan University Students' Perceptions of Summative and Formative Classroom Assessment in English Courses. TESOL International Journal, 15(2), 46. ISSN 2094-3938.

Pooja, B. (2013) English for Employability: A Challenge for ELT Faculty. Research Journal of English Language and Literature, 1(3), 351.

Totanes, B. C., \& Arceli, M. A. (2020). Critical Scaffolding Method: A Proposed Instructional Strategy on Critical Literacy in Reading English Literary Texts. The Asian EFL Journal September, 5(24).

Wall, D. (1997). Impact and Washback in Language Testing. In C. Clapham \& D. Corson (Eds.), Encyclopaedia of Language and Education (7: Language Testing and Assessment, pp. 291-302). Dordrecht: Kluwer Academic. https://doi.org/10.1007/978-1-4020-4489-2_26

Weir, C. J. (1987). Communicative Language Testing with Special Reference to English as a Foreign Language. Exeter Linguistics Studies. RRR. Hartmann; University of Exter.

\section{Appendix A}

\section{Questionnaire cum Opinionnaire for EFL Faculty at graduation level}

Topic: ELT Assessment Patterns Dictate Teaching-Learning Approaches: A Hindrance to Map out Employability and Life Skills

Name: Last Degree:

Specialization: Subject teaching experience: Years

Email id:

Note: Kindly respond to the questions reflecting your valuable real experience for the EFL better future. This is a contribution to develop employability and life skills in our EFL learners. Well thought responses are requested. 


\section{Section 1}

\begin{tabular}{|c|c|c|c|c|}
\hline Q.No. & Question & Yes & No & To some extent \\
\hline 1 & Do you ensure validity of the test items in the EFL formative and summative assessments? & & & \\
\hline 2 & Are the test items in your formative and summative assessment the same? & & & \\
\hline 3 & Do the assessment patterns harness your teaching approaches? & & & \\
\hline 4 & Do you prepare your EFL learners for the predetermined and fixed test items? & & & \\
\hline 5 & $\begin{array}{l}\text { Are you free to make a choice for some test items/activities that may help developing employability } \\
\text { and life skills? }\end{array}$ & & & \\
\hline 7 & Do students' groups present some topics in classroom? & & & \\
\hline 8 & Are you satisfied with the students' interest and teamwork? & & & \\
\hline 9 & Do your EFL students accept all challenging assignments cheerfully? & & & \\
\hline 10 & Are your students familiar with the importance of soft skills? & & & \\
\hline 11 & Are you satisfied with the traditional ways of assessments? & & & \\
\hline 12 & Do you think EFL learners' 'Peer Assessment' is useful for developing their confidence and creativity? & & & \\
\hline 14 & Do you think EFL is being taught and assessed as a subject rather than a language? & & & \\
\hline 15 & Are all EFL skills covered in formative and summative assessment? & & & \\
\hline 16 & $\begin{array}{l}\text { The students attempt their traditional EFL assessment tests through their cramming and rote learning } \\
\text { and not as creative writers using critical thinking. Do you agree? }\end{array}$ & & & \\
\hline 17 & Do you think that employability skills can be developed through co-curricular activities? & & & \\
\hline 18 & $\begin{array}{l}\text { Are your EFL students well motivated to be competent in the use of tangible and intangible skills for } \\
\text { their bright future? }\end{array}$ & & & \\
\hline
\end{tabular}

\section{Section 2}

19. What are the most common test items in EFL assessments?
Subjective Objective Mixed one

20. Your subjective assessment items include:

(a)

(b)

(c)

(d)

(e)

(f)

21. Your objective test items generally include:
(a)
(b)
(c)
(d)
(e)
(f)

22. What are the other test's items that you would like to include in formative and summative assessment of EFL?

(a)

(b)

(c)

(d)

(e)

23. What type of activities and assignments are common is your classroom? 
(a)

(b)

(c)

(d)

(e)

24. What does restrain you back from developing the most wanted employability and life skills in the EFL teaching? Kindly comment whatever you experienced so far.

25. How can we transform the existing assessment patterns into the prevailing demand of the employers?

\section{Appendix B}

\section{Questionnaire cum Opinionnaire for EFL Learners at graduation level}

Topic: ELT Assessment Patterns Dictate Teaching-Learning Approaches: A Hindrance to Map out Employability and Life Skills

Name:

Id:

Level:

Note: Kindly respond to the questions reflecting your valuable real experience in the classroom, for EFL better future. This is a contribution to develop employability and life skills in our EFL learners.

\section{Section 1}

\begin{tabular}{|c|c|c|c|c|}
\hline Q.No. & Question & Yes & No & To some extent \\
\hline 1 & $\begin{array}{l}\text { Do you think the test items in the EFL formative and summative assessments are valid (means fulfill } \\
\text { the aims of testing EFL learner' skills and competency)? }\end{array}$ & & & \\
\hline 2 & Are the test items in your formative and summative assessments the same? & & & \\
\hline 3 & Do the assessment patterns harness (control) your EFL study and preparation for examinations? & & & \\
\hline 4 & Are you prepared by the English instructor only for the predetermined and fixed test items? & & & \\
\hline 5 & $\begin{array}{l}\text { Are you free to make a choice for some activities that may help developing your employability and life } \\
\text { skills? }\end{array}$ & & & \\
\hline 6 & Are problem solving activities and assignments common in your classroom? & & & \\
\hline 7 & Do students' groups present some topics in classroom? & & & \\
\hline 8 & $\begin{array}{l}\text { Are you satisfied with your classmates' interest and teamwork in preparation of classroom } \\
\text { presentation? }\end{array}$ & & & \\
\hline 9 & Do you and your EFL classmates accept all challenging assignments cheerfully? & & & \\
\hline 10 & Are you familiar with the importance of soft skills? & & & \\
\hline 11 & Are you satisfied with the traditional ways of assessments? & & & \\
\hline 12 & Do you think the 'Peer Assessment' is useful for developing EFL learners' confidence and creativity? & & & \\
\hline 13 & Would you like the idea of students' 'Self-Assessment' in EFL classroom? & & & \\
\hline 14 & Do you think EFL is being taught and assessed as a subject rather than a language? & & & \\
\hline 15 & Are all EFL skills covered in your formative and summative assessment? & & & \\
\hline 16 & $\begin{array}{l}\text { Do you attempt your EFL assessment tests through your cramming and rote learning and not with } \\
\text { critical thinking? }\end{array}$ & & & \\
\hline 17 & Do you think that your employability skills can be developed through co-curricular activities? & & & \\
\hline 18 & $\begin{array}{l}\text { Are you as an EFL student well motivated to be competent in the use of tangible and intangible skills } \\
\text { for your bright future? }\end{array}$ & & & \\
\hline
\end{tabular}

\section{Section 2}

19. What are the most common test items in your EFL assessments? 
Subjective

Objective

Mixed one

20. Your subjective assessment items include:

(a)

(b)

(c)

(d)

(e)

(f)

21. Your objective test items generally include:

(a)

(b)

(c)

(d)

(e)

(f)

22. What are the other test's items that you would like to include in your formative and summative assessment of the EFL that may add to your confidence toward using English in real-life-like situations?

(a)

(b)

(c)

(d)

(e)

23. What type of activities and assignments are common is your classroom?

(a)

(b)

(c)

(d)

(e)

24. What does restrain you back from developing the most wanted employability and life skills during EFL learning process? Please comment whatever you experienced so far.

25. How can we transform the existing assessment patterns into the prevailing demand of the employers? Please give some suggestions.

\section{Copyrights}

Copyright for this article is retained by the author, with first publication rights granted to the journal.

This is an open-access article distributed under the terms and conditions of the Creative Commons Attribution license (http://creativecommons.org/licenses/by/4.0/). 